\title{
Effect of different nitrogen sources on phytoplankton composition in aquaculture ponds
}

\author{
Michele A. Burford ${ }^{1,2, *}$, Douglas C. Pearson ${ }^{3}$ \\ ${ }^{1}$ CSIRO Division of Marine Research and ${ }^{2}$ Cooperative Research Centre for Aquaculture, PO Box 120, Cleveland, \\ QueensIand 4163, Australia \\ ${ }^{3}$ Gold Coast Marine Hatchery, Woongoolba, Queensland 4207, Australia
}

\begin{abstract}
Phytoplankton species composition, succession and water quality were monitored over $7 \mathrm{~d}$ in 6 penaeid prawn ponds. They were filled simultaneously with water; 3 were fertilized with urea and 3 with sodium nitrate to give equivalent nitrogen concentrations. Neither chlorophyll a concentration nor phytoplankton cell counts differed between treatments. Phytoplankton species diversity was low with only 2 phytoplankton species present, the diatom Nitzschia sp. and the dinoflagellate Prorocentrum minimum. Adjacent ponds had similar trends in cell numbers irrespective of nitrogen source. Initially Nitzschia sp. grew more rapidly, outcompeting P. minimum in all ponds. There were differences in the growth of Nitzschia sp. that appeared to be related to the position of the pond along the inlet channel. Urea and nitrate uptake was rapid, with concentrations decreasing from $34 \mu \mathrm{M}$ nitrogen to below $1 \mu \mathrm{M}$ within $3 \mathrm{~d}$. Nitzschia sp. numbers decreased in 2 ponds after this time but in the other 4 continued to increase until Days 6 and 7. P. minimum numbers remained low for the first 4 to $5 \mathrm{~d}$ then increased in 5 of the 6 ponds. There were no significant differences in water temperature, oxygen, phosphate and ammonia concentrations between the 2 treatments. $\mathrm{pH}$ was significantly higher in the nitrate treatment than in the urea treatment, probably due to the dissolution products of these compounds in seawater. The results suggest that the differential response of phytoplankton species to nutrients, and interactions between species, may be more important than the form of nitrogen available in determining phytoplankton species composition and succession.
\end{abstract}

KEY WORDS: Urea $\cdot$ Nitrate $\cdot$ Nutrients $\cdot$ Penaeid $\cdot$ Shrimp $\cdot$ Prorocentrum $\cdot$ Nitzschia

\section{INTRODUCTION}

Nitrogen is an essential element for phytoplankton growth. Almost all chlorophyll-containing algae will grow on either nitrate or ammonium, and in general the amides, urea, glutamine and asparagine, are also utilized (Syrett 1981). Ammonium is the most efficiently used form: it requires 401 to $454 \mu \mathrm{mol}$ photons to synthesize $1 \mathrm{mg}$ protein whereas nitrate requires 598 to $651 \mu \mathrm{mol}$ photons (Raven 1984). It is also taken up faster and has a lower saturation constant than nitrate (Dortch 1990); both characteristics are accentuated by low light and nitrogen availability. Despite this, the growth rates of phytoplankton on nitrate may equal or exceed those on ammonium, depending on the

•E-mail: michele.burford@marine.csiro.au light regime. At high photon flux densities ( $>29 \mu \mathrm{mol}$ $\mathrm{s}^{-1} \mathrm{~m}^{-2}$ ) cells grown on nitrate had lower growth rates than cells grown on ammonium, but not at lower flux densities (Thompson et al. 1989). The use of nitrate rather than ammonium therefore seems to be of little energetic importance. Levasseur et al. (1993) found that when growth was light-limited, 2 diatom species, a green flagellate and a dinoflagellate, grew at the same rate on either nitrate or ammonium. The diatom species also grew at the same rate on urea.

Nitrogen availability can also affect the relative rates of nitrate and ammonium uptake (Dortch 1990). Low nitrogen availability may increase the preference for ammonium uptake, but despite this, growth on nitrate is often as rapid as or better than that on ammonium. Temperature also has an effect, but there is no consensus about whether nitrate or ammonium is more temperature dependent. 
Urea dissolves quickly in water but hydrolyses very slowly to yield carbon dioxide and ammonia (Chin \& Kroontje 1963). Microalgae and other microbes assimilate urea by way of the enzyme urease or ATP:urea amidolyase (Mitamura \& Saijo 1975, Kristiansen 1983, Antia et al. 1991). In several field studies, urea as a nitrogen source was intermediate between that for ammonium and nitrate (Antia et al. 1991). However, the presence of ammonium can suppress urea uptake; the degree of suppression is dependent on ammonium concentration, nitrogen status of cells and the species.

Syrett (1981) suggests that there is no clear relationship between the ability to use a particular group of nitrogen compounds and taxonomic class. However, Robert et al. (1986) found that diatom growth was promoted by inorganic nitrogen sources, and flagellate growth was promoted by urea. Other researchers have found a higher proportion of netplankton (predominantly diatoms) than nanoplankton in nitrate-rich waters (Malone 1980, Glibert et al. 1982, Probyn 1985. Kokkinakis \& Wheeler 1988).

The effect of different forms of nitrogen on the dominance and succession of phytoplankton species in aquaculture ponds has received little attention. To stimulate phytoplankton blooms in penaeid prawn ponds, fertilizers containing urea, chicken manure and sodium nitrate are commonly added (Clifford 1992). The blooms provide food and shade, prevent the growth of undesirable benthic algae, reduce toxic ammonia concentrations and increase oxygen levels (Chien 1992, Burford 1997). Maintenance of blooms to achieve acceptable water quality is a constant challenge for aquaculturists; poor water quality can result in stressed and diseased prawns (Phillips et al. 1993).

The aim of our study was to compare the effect on phytoplankton species composition and succession of fertilizing commercial aquaculture ponds with either urea or sodium nitrate. In addition, the effect of these fertilizers on water quality was examined.

\section{METHODS}

The study site was a commercial penaeid prawn farm (Gold Coast Marine Hatchery), in subtropical, southeast Queensland (Australia) near the mouth of the Logan River $\left(27^{\circ} 45^{\prime} \mathrm{S}, 153^{\circ} 20^{\prime} \mathrm{E}\right)$. This farm produces the black tiger prawn Penaeus monodon in ponds in the summer months

The ponds are $100 \mathrm{~m}$ wide $\times 100 \mathrm{~m}$ long, earth-lined and with a water depth of about $1.4 \mathrm{~m}$. One day before the experiment began, 6 ponds were filled with water from an inlet channel that had, 1 wh before, been filled from the estuary. The ponds were aerated using paddle- wheels for the $9 \mathrm{~d}$ of the experiment. No prawns were stocked.

There were 2 treatments: 3 ponds had $29 \mathrm{~kg}$ sodium nitrate $(99.6 \%)$ added by broadcasting a wet slurry into the ponds, and 3 ponds had $10 \mathrm{~kg}$ urea (agricultural grade) added as a dry powder broadcast into the ponds on Day 0. The final concentration added was $34 \mu \mathrm{M}$ nitrogen in all ponds. Alternate ponds along the length of the inlet channel were fertilized with either of the 2 treatments to ensure that variations in water quality along the inlet channel were accounted for. On Day 2, $7 \mu \mathrm{M}$ nitrogen was added to all ponds, and on Day 5, $14 \mu \mathrm{M}$ nitrogen was also added.

Temperature, salinity, oxygen and $\mathrm{pH}$ were monitored twice a day (at dawn and at dusk) for 1 wk with a datalogger (TPS) deployed off a jetty. The water sampling strategy was based on previous analyses that showed that the waters were well mixed; hence, sampling at 1 place was sufficient to represent the pond as a whole (Burford 1997). Every day at the same time, duplicate water samples were taken off the jetty and filtered through GF/F glass fibre filters. The filters were frozen for chlorophyll a and pigment analysis. Every $2 \mathrm{~d}$, the filtrate was frozen for urea, nitrate, ammonia and phosphate analyses. Water samples were also taken daily and fixed with $1 \%$ glutaraldehyde for cell counts of microalgae. Additional samples were taken on Day 9 for cell counts.

Urea was analysed by the diacetyl monoxime method (Rahmatullah \& Boyde 1980), and ammonia, nitrate and phosphate were analysed by American Public Health Association (1989) methods. Pigments were extracted in $100 \%$ cold methanol, sonicated for $1 \mathrm{~min}$, filtered and analysed by high-performance liquid chromatography (HPLC) (Burford 1997). Phytoplankton were counted with a haemocytometer under bright field illumination using a compound microscope at $200 \times$ magnification. Higher magnification $(400 \times)$ was also used to examine samples for nano- and picoplankton.

The water quality data were tested for normality, and a 2-way ANOVA test comparing days and fertilizers for each water quality parameter was performed. Pond position versus fertilizer was also tested using ANOVA. For this analysis, water quality parameters were time-integrated over $7 \mathrm{~d}$.

\section{RESULTS}

The mean and standard deviation of salinity of all ponds was $35.4 \pm 0.1$ Water temperature ranged from $18.3 \pm 0.2^{\circ} \mathrm{C}$ in all ponds in the morning to $23.9 \pm 0.2^{\circ} \mathrm{C}$ in the evening (Fig. 1a) and was not significantly different between treatments (Table 1). The mean initial 

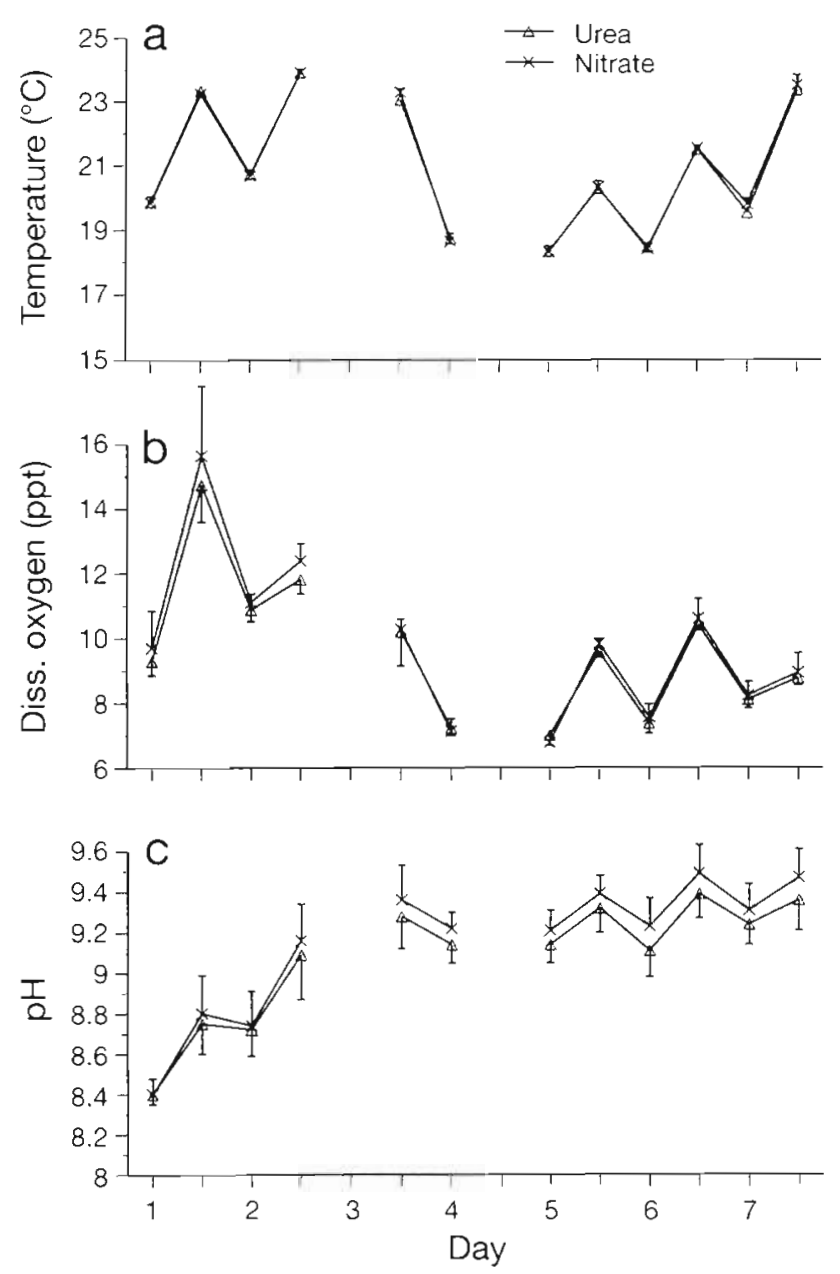

Fig. 1. Mean morning and evening measurements and standard deviation of (a) water temperature, (b) oxygen, and (c) pH in ponds fertilized with either urea or nitrate. Gaps indicate no data

dissolved oxygen level was $9.5 \pm 0.8$ ppt in the morning, rising to $15.2 \pm 1.6 \mathrm{ppt}$ in the evening; by the morning of Day 4 it had decreased to $7.1 \pm 0.3$ ppt (Fig. 1 b).

Table 1 F-tests comparing fertilizers (urea or nitrate) for the water quality parameters in all ponds from 7 sampling days. $\mathrm{N}$ : number of samples taken

\begin{tabular}{|llr|}
\hline Parameter & Fertilizer & $\mathrm{N}$ \\
\hline Temperature & 0.5155 & 12 \\
Oxygen & 0.1752 & 12 \\
$\mathrm{pH}$ & $0.0295^{\circ}$ & 12 \\
Nitrate & $0.0001 \cdots$ & 4 \\
Urea & $0.0001^{\circ} \cdots$ & 4 \\
Ammonia & 0.3677 & 4 \\
Phosphate & 0.1032 & 4 \\
Chlorophyll a & 0.9282 & 8 \\
Nitzschia sp. & 0.5379 & 8 \\
Prorocentrum minimum & 0.0550 & \\
'p<0.05, $\cdots p<0.005$ & & \\
\hline
\end{tabular}

There were no statistical differences between treatments (Table 1). The mean and standard deviation of $\mathrm{pH}$ was $8.4 \pm 0.1$ on the first morning rising to $8.8 \pm 0.2$ in the evening and gradually increasing to $9.3 \pm 0.1$ in the evening of Day 3 and $9.2 \pm 0.1$ in the morning of Day 4 (Fig. 1c). pH was statistically lower $(\mathrm{p}<0.05)$ in the urea treatment than the nitrate treatment (Table 1).

Based on the amount of urea added to Ponds 1, 3 and 5 , the urea-nitrogen concentration on Day 0 was $34 \mu \mathrm{M}$ (Fig. 2). By Day 1, concentrations in the ponds ranged from 8 to $20 \mu \mathrm{M}$. Within $2 \mathrm{~d}$ concentrations had decreased to $2 \mu \mathrm{M}$ and remained at a concentration of 2 to $4 \mu \mathrm{M}$ for the duration of the experiment despite the addition of fertilizers on Days 2 and 5. Nitrate plus nitrite concentrations remained at less than $2 \mu \mathrm{M}$ for the duration of the experiment (Fig. 2).

Based on the amount of nitrate added, the nitratenitrogen concentration in Ponds 2, 4 and 6 on Day 0 was $34 \mu \mathrm{M}$ (Fig. 2). The nitrate plus nitrite concentration ranged from 15 to $40 \mu \mathrm{M}$ on Day 1 , and decreased within $2 \mathrm{~d}$ to $1 \mu \mathrm{M}$ or less. It rose in Ponds 2 and 4 on.
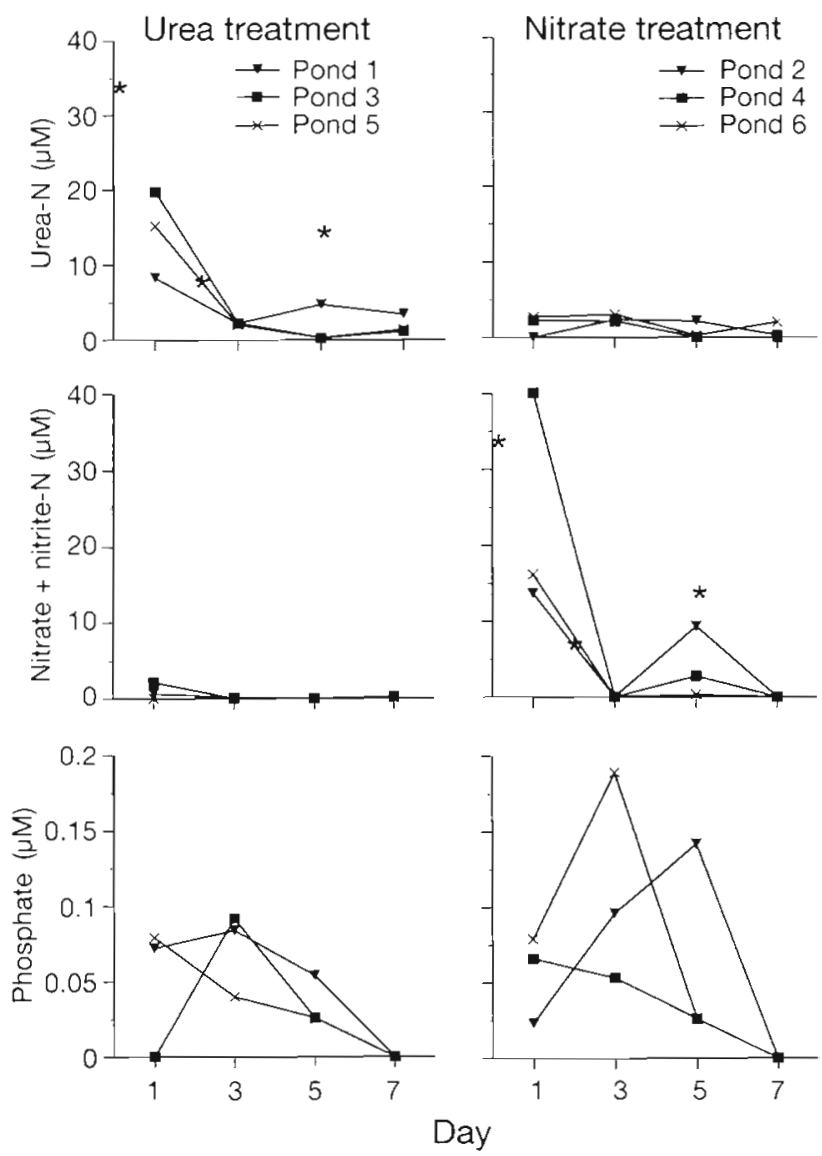

Fig. 2. Concentrations of urea-nitrogen, nitrate plus nitritenitrogen and phosphate in ponds fertilized with either urea or nitrate. (*) Timing and concentration of either urea or nitrate fertilization 
Day 5 when ponds were fertilized. Urea concentrations remained at less than $1 \mu \mathrm{M}$ for the duration of the experiment (Fig. 2). There were significant differences in the urea and nitrate concentrations of the 2 treatments (Table 1).

Ammonia concentrations in all ponds were below the detection limit $(<0.7 \mu \mathrm{M})$ throughout the experiment. In both treatments, the phosphate concentrations ranged from 0 to $0.08 \mu \mathrm{M}$ at the beginning of the experiment (Fig. 2). By Day 7 they decreased to undetectable levels. Phosphate concentrations were not significantly different between treatments (Table 1).

Chlorophyll a concentrations initially ranged from 25 to $35 \mu \mathrm{g} \mathrm{l}^{-1}$ and gradually increased in all ponds for the first $3 \mathrm{~d}$ after which they plateaued or decreased until Day 6, when they began to increase again (Fig. 3). The greatest increase was in 'urea' Pond 5 and 'nitrate' Pond 6 where chlorophyll a concentrations rose to over $100 \mathrm{\mu g} \mathrm{l}^{-1}$. There were no significant differences in mean concentrations between treatments (Table 1).

Two phytoplankton species constituted over $95 \%$ of the algae in all ponds: a diatom Nitzschia sp. (volume $800 \mathrm{\mu m}^{3}$ ) and a dinoflagellate Prorocentrum minimum (volume $4000 \mu \mathrm{m}^{3}$ ). The numbers of the 2 species after nutrient addition varied from pond to pond: Nitzschia sp. ranged from $5 \times 10^{4}$ to $1 \times 10^{5} \mathrm{ml}^{-1}$, and $P$. minimum ranged from $2 \times 10^{4}$ to $5 \times 10^{4} \mathrm{ml}^{-1}$ (Fig. 4). HPLC pigment analyses were done to compliment the cell counts. Peridinin, a dinoflagellate pigment, and fucoxanthin, a diatom and prymnesiophyte pigment, were present. Pigments indicative of other algal groups were not detected.

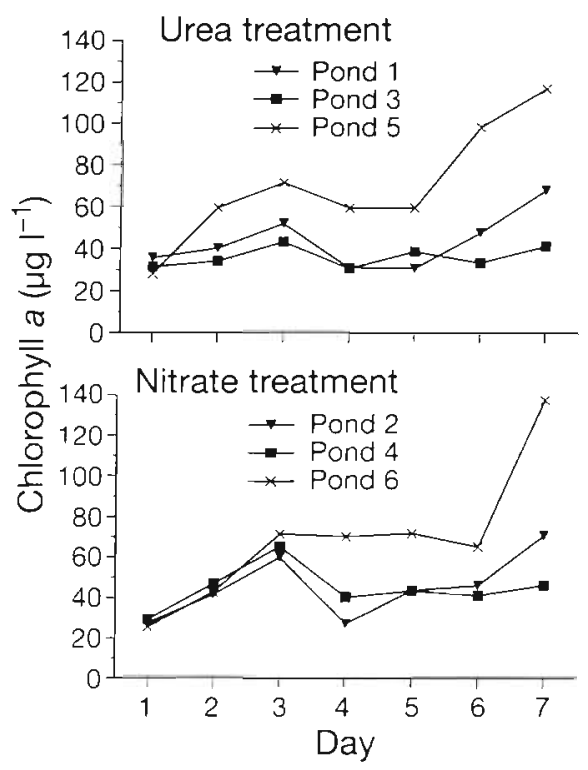

Fig. 3. Chlorophyll a concentrations in ponds fertilized with either urea or nitrate

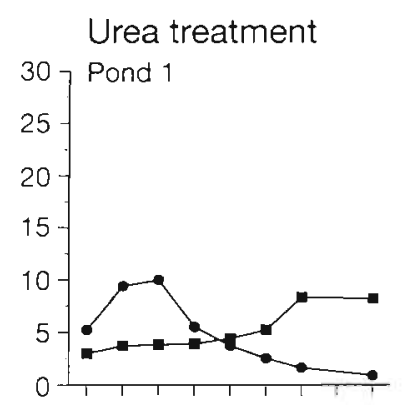

Nitrate treatment
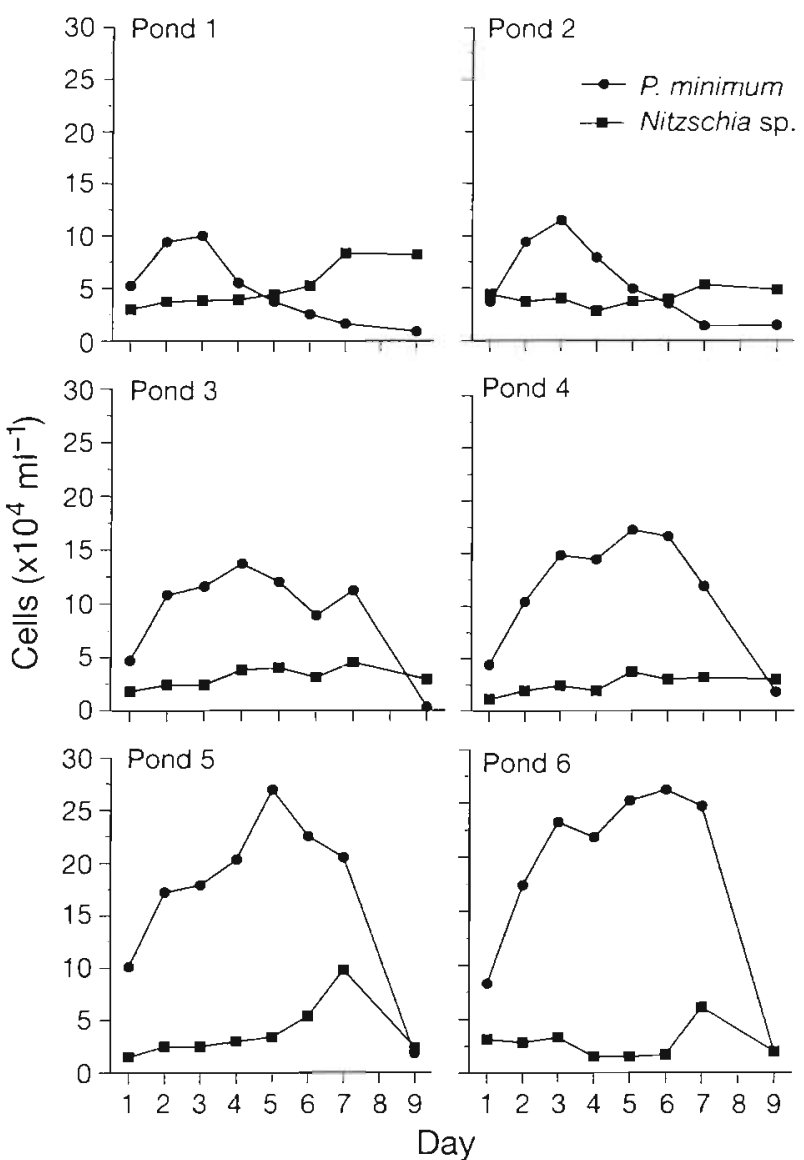

Fig. 4. Cell counts of Nitzschia sp. and Prorocentrum minimum sp. in ponds fertilized with urea (Ponds 1,3 and 5) and nitrate (Fonds 2, 4 and 6)

The response to urea fertilization varied from pond to pond. In Pond 1, Nitzschia sp. numbers increased from $5 \times 10^{4}$ to $1 \times 10^{5} \mathrm{ml}^{-1}$ in the first $3 \mathrm{~d}$ then decreased to $0.9 \times 10^{4} \mathrm{ml}^{-1}$ by Day 9 (Fig. 4 ). In contrast, Prorocentrum minimum numbers remained at $3 \times 10^{4}$ $\mathrm{ml}^{-1}$ until Day 4, when they increased to $8.3 \times 10^{4} \mathrm{ml}^{-1}$. In Pond 3, Nitzschia sp. numbers increased for the first $3 \mathrm{~d}$ to $14 \times 10^{4} \mathrm{ml}^{-1}$, remained constant until Day 7 , then decreased to $0.3 \times 10^{4} \mathrm{ml}^{-1}$ by Day 9. P. minimum numbers remained low. In Pond 5, Nitzschia sp. numbers increased for the first $4 \mathrm{~d}$ to a peak of $27 \times 10^{4} \mathrm{ml}^{-1}$, then decreased to $1.8 \times 10^{4} \mathrm{ml}^{-1}$ by Day 9. P. minimum numbers were low except for a peak on Day 7 $\left(10^{5} \mathrm{ml}^{-1}\right)$

Trends in the nitrate fertilized ponds also varied from pond to pond and closely resembled the adjacent ponds fertilized with urea (Fig. 4). The trend in Pond 2 was similar to that of the adjacent Pond 1. Nitzschia sp. numbers increased until Day 3 then declined throughout the remainder of the experiment. Prorocentrum minimum numbers remained constant until Day 7 
Table 2. F-tests comparing fertilizer (urea or nitrate) and position of pond along the inlet channel for the time-integrated water quality parameters in all ponds at Gold Coast Marine Hatchery, Queensland, Australia

\begin{tabular}{|lcc|}
\hline Parameter & Fertilizer & Pond position \\
\hline Temperature & 0.6817 & 0.0962 \\
Oxygen & 0.3450 & 0.1859 \\
pH & 0.3672 & 0.0781 \\
Nitrate & 0.0847 & 0.8470 \\
Urea & 0.0244 & 0.4399 \\
Ammonia & 0.1189 & 0.6713 \\
Phosphate & 0.9851 & 0.3087 \\
Chlorophyll a & 0.7827 & 0.0564 \\
Nitzschia sp. & 0.0592 & 0.0001 \\
Prorocentrum minimum & 0.2287 & 0.2710 \\
-p<0.05 & & \\
\hline
\end{tabular}

when they increased. The trend in Pond 4 was similar to that of the adjacent Pond 3: Nitzschia sp. numbers increased for the first $5 \mathrm{~d}$, from $4.4 \times 10^{4}$ to $16 \times 10^{4} \mathrm{ml}^{-1}$, and then decreased to $1.3 \times 10^{4} \mathrm{ml}^{-1}$ by Day $9 . P$. minimum numbers increased slightly during the experiment. In Pond 6, Nitzschia sp. numbers increased to $26 \times 10^{4} \mathrm{ml}^{-1}$ by Day 6 then decreased to $2 \times 10^{4} \mathrm{ml}^{-1}$ by Day 9. $P$. minimum numbers remained low, with a short-lived increase on Day 7. There were no significant differences between treatments in the mean numbers of Nitzschia sp. or P. minimum (Table 1). A protozoan containing ingested $P$. minimum was common in many ponds on Day 9.

Differences in water quality parameters among ponds along the inlet channel were examined statistically by time-integrating values over $7 \mathrm{~d}$ (Table 2). There were no significant differences relating to pond position for all water quality parameters. However, Nitzschia sp. time-integrated values increased along the inlet channel. When the effect of fertilizer sources was examined using time-integrated values, only urea was significant.

\section{DISCUSSION AND CONCLUSIONS}

Our experiment found no difference over $9 \mathrm{~d}$ in either species composition or succession in ponds fertilized with nitrate or urea. In all 6 ponds, the diatom Nitzschia sp. dominated initially and was then displaced by the dinoflagellate Prorocentrum minimum. However the low species diversity in this experiment does not give an indication of how a more diverse community may respond to these fertilizers. The dominance of particular algal groups in aquaculture ponds is affected by physical, chemical and biological factors such as salinity (Chien 1992) and light (Levasseur et al. 1984, Burford 1997), pond-flushing regimes (Tseng et al. 1991), nitrogen to phosphorus ratios (Paerl \& Tucker 1995), and availability and form of nutrients (Boyd 1995)

There is disagreement in the oceanographic literature about whether there is a relationship between taxonomic class and the ability to use a particular group of nitrogen compounds. Syrett (1981) found no relationship while others have reported a higher proportion of netplankton (predominantly diatoms) than nanoplankton in nitrate-rich waters in coastal regions and vica versa in nutrient-poor waters (Malone 1980, Glibert et al. 1982, Probyn 1985, Kokkinakis \& Wheeler 1988). Robert et al. (1986) found evidence that diatoms grew better on inorganic nitrogen sources, whereas flagellates grew better on urea in oyster ponds.

In our experiment, the rate at which algal species grew appeared to determine species dominance, i.e. Nitzschia sp. initially grew more rapidly than Prorocentrum minimum. It has previously been shown that small diatoms grow rapidly when nutrients are increased (Guillard \& Kilham 1977). P. minimum has higher growth rates compared with other dinoflagellates (maximum of 1.15 divisions $\mathrm{d}^{-1}$ ), but these growth rates are lower than those of coastal diatoms (more than 1 division $d^{-1}$ ) (Guillard \& Kilham 1977, Grzebyk \& Berland 1996). Nitzschia sp. numbers decreased in all the ponds after a fcw days. Possibly silicate was depleted silicate to phosphorus and silicate to nitrogen ratios affect diatom dominance (Sommer 1989 , 1996). We did not measure silicate during the experiment, but values were low in all ponds on Day $9(0.10$ to $0.53 \mu \mathrm{M}$ ). This may explain why Nitzschia sp. numbers were low at this time

Prorocentrum minimum, in contrast to Nitzschia sp., increased in numbers with time as nutrient levels declined. Sciandra (1991) found that when nitrate was supplied infrequently, uptake and growth rate become largely uncoupled in $P$. minimum. Presumably this species can conserve nitrogen, giving it a competitive advantage in low-nutrient waters. This ability would also limit the nitrogen available for other species.

High primary productivity is often accompanied by a decrease in the carbon dioxide concentration and attendant increase in $\mathrm{pH}$ (Berman-Frank et al. 1994). Blooms of dinoflagellate Peridinium gatunense in Lake Kinneret, Israel, with high primary productivity rates (exceeding $3 \mathrm{~g} \mathrm{C} \mathrm{m}^{-2} \mathrm{~d}^{-1}$ ), increased the $\mathrm{pH}$ and decreased the carbon dioxide concentration (Pollinger \& Berman 1982, Berman-Frank et al. 1994). Carbonic anhydrase, an enzyme that converts sodium bicarbonate to carbon dioxide, also increased. A species' ability to adapt to low carbon dioxide levels is related to the activity of this enzyme (Tsuzuki \& Miyachi 1989). The ponds used in our experiments had high primary productivities $\left(2.42 \pm 0.55 \mathrm{~g} \mathrm{C} \mathrm{m}^{-2} \mathrm{~d}^{-1}\right.$ ) (Burford 1997), 
which were similar to those reported by Pollinger \& Berman (1982), so carbon dioxide limitation is possible. Furthermore inorganic carbon was found to be a limiting nutrient in fish ponds (Shrestha \& Kwei Lin 1996). Thus species dominance and succession in our experiment may also be related to the ability of species to adapt to low carbon dioxide conditions.

Smayda (1980) has defined changes in phytoplankton species dominance in terms of successional stages. Stage I is typical of turbulent and nutrient-enriched waters, dominated by small-celled diatoms with high ratios of cell surface area:cell volume and potentially high rates of increase. In our experiment, the rapid growth of Nitzschia sp. reflects stage I. Stage II is a more mixed community of large-celled diatoms and dinoflagellates with lower potential growth rates and lower ratios of cell surface area:cell volume. We found a rapid decrease in Nitzschia sp. numbers and a gradual increase in the larger, slower-growing Prorocentrum minimum as nutrients declined. However, the $P$. minimum bloom was sustained in some ponds but not others, possibly the result of protozoan grazing. Uchida (1977) observed diatom blooms followed by a Prorocentrum micans bloom in Muroran harbour, Hokkaido (Japan), and showed that P. micans produced compounds which inhibit the growth of other dinoflagellates and diatoms. Other researchers have found similar effects (Gauthier et al. 1978, Kayser 1979). It is proposed that these compounds play an important role in Prorocentrum bloom development. Conversely organic substances excreted by Skeletonema costatum and Nitzschia closterium can stimulate the growth of P. minimum (Kondo et al. 1990).

Maintenance of stable phytoplankton blooms is an ongoing challenge for aquaculturists, but the literature on the dominance and successional patterns of phytoplankton species in aquaculture ponds is largely anecdotal. Tucker (1994) suggests that, in freshwater pond conditions where phytoplankton are not limited by nutrients, communities tend to have a low species diversity and may be dominated by gas-vacuolate bluegreen algae. Chien (1992) suggests that diatom blooms are unstable, whereas green flagellates have a more stable bloom because of their slower growth rates.

The similarity in algal species composition among ponds in our study is the result of simultaneous filling of the ponds and no water exchange. However, over longer time periods, phytoplankton communities vary considerably among ponds, in part because all ponds are managed on a reactive basis. Ponds are fertilized at different times and with different dosages depending on the status of the algal bloom, animal feeding rates vary and the frequency and intensity of discharging and re-filling of ponds to stabilize algal blooms vary from pond to pond. In addition, soil conditions can affect nutrient availability. There were differences in cell numbers, particularly of Nitzschia sp. between ponds. This was probably because of poor mixing in the inlet channel that resulted in higher numbers of this species entering some ponds than others.

Phytoplankton have an important role in nitrogen cycling in aquaculture ponds. In shrimp ponds at moderate stocking densities, they effectively assimilate ammonium generated by shrimp excretion (Lorenzen et al. 1997). At higher stocking densities, soluble nitrogen accumulates because regeneration exceeds phytoplankton uptake. Uptake may be limited by light availability since light is a key limiting factor to phytoplankton growth (Burford 1997). Bacteria also assimilate and regenerate nitrogen compounds however their role in marine aquaculture ponds is not well understood (Moriarty 1986)

Sodium nitrate has been suggested as a preferable fertilizer to urea and ammonium-based fertilizers because it is a natural product and does not require a fuel intensive, synthetic processing step (Boyd 1995). The addition of nitrate to seawater may also have increased the $\mathrm{pH}$ due to the dissolution processes in seawater Conversely urea and ammonia can decrease $\mathrm{pH}$ by the production of hydrogen ions, whereas nitrate increases pH as it dissolves (Brewer \& Goldman 1976, Boyd 1995). Our results showed that $\mathrm{pH}$ was higher in the nitrate-fertilized than in the urea-fertilized ponds, but the differences were not great. Nitrate is also less toxic to fish and penaeid prawns than ammonia, the disassociation product of urea. Our results show that over $7 \mathrm{~d}$ there are no differences in ammonia levels when either sodium nitrate or urea was used as fertilizer sources for stimulating blooms in penaeid prawn ponds. The similarity in the water quality parameters between treatments in our experiment may be due, in part, to the rapid uptake of nutrients as within $2 \mathrm{~d}$ the concentrations of urea and nitrate were low.

Our study showed that in the short term, fertilization of penaeid prawn ponds by nitrate or urea had similar effects on phytoplankton dominance, successional patterns and water quality (with the exception of $\mathrm{pH}$ ). Therefore the use of nitrate was not effective in improving water quality or changing phytoplankton dominance. However, the species diversity in this experiment was low, and this result may not necessarily be reproducible with higher species diversity. The observed changes in phytoplankton dominance may be the result of differential responses to nutrients such as silicate. Inhibition or stimulation effects between the 2 species could also be having an effect. However, more research is needed to determine the dominant factors affecting phytoplankton species composition and succession in order to improve phytoplankton bloom stability in aquaculture ponds. 
Acknowledgements. This work was funded by the CRC for Aquaculture and CSIRO Division of Marine Research. Vanessa Fry and Frances Coman helped with the sampling, Joshua Mylne with nutrient analyses, Christopher Bolch with phytoplankton identification and Peter Thompson, Cynthia Heil, Vivienne Mawson and Peter Rothlısberg gave constructive criticisms of the manuscript

\section{LITERATURE CITED}

American Public Health Association (1989) Standard methods for the exammation of water and wastewater. In: Clesceri LS, Greenberg AE, Rhodes Trussell R (eds) 17th edn. APHA, Washington, DC

Antia NJ, Harrison PJ, Oliveira L (1991) The role of dissolved organic nitrogen in phytoplankton nutrition, cell biology and ecology. Phycologia 30:1-89

Berman-Frank I, Zohary T, Erez J, Dubinsky Z (1994) $\mathrm{CO}_{2}$ availability, carbonic anhydrase, and the annual dinoflagellate bloom in Lake Kinneret. Limnol Oceanogr 39: $1822-1834$

Boyd CE (1995) Potential of sodium nitrate to improve environmental conditions in aquaculture ponds. World Aquacult 26:38-40

Brewer PG, Goldman JC (1976) Alkalinity changes generated by phytoplankton growth. Limnol Oceanogr 21:108-117

Burford MA (1997) Phytoplankton dynamics in shrimp ponds Aquac Res 28:351-360

Chien YH (1992) Water quality requirements and management for marine shrimp culture. In: Wyban J (ed) Proceedings of the special session on shrimp farming. World Arguaculture Society, Baton Rouge, p 30-42

Chin W, Kroontje W (1963) Urea hydrolysis and subsequent loss of ammonia. Soil Sci 140:81-88

Clifford HC (1992) Marine shrimp pond management: a review. In: Wyban J (ed) Proceedings of the special session on shrimp farming. World Aquaculture Society, Baton Rouge, p 100-137

Dortch $Q$ (1990) The interaction between ammonium and nitrate uptake in phytoplankton. Mar Ecol Prog Ser 61: $183-201$

Gauthier MJ, Bernard P, Aubert M (1978) Modification de la fonction antibiotique de deux diatomées marines, Asterionella japonica (Cleve) et Chaetoceros lauderi (Ralfs), par de dinoflagellé Prorocentrum micans (Ehrenberg). J Exp Mar Biol Ecol 33:37-50

Glibert PM, Goldman JC, Carpenter EJ (1982) Seasonal variations in the utiluzation of ammonium and nitrate by phytoplankton in Vineyard Sound, Massachusetts, USA. Mar Biol 70:237-249

Grzebyk D, Berland B (1996) lnfluences of temperature, salinity and irradiance on growth of Prorocentrum minimum (Dinophyceae) from the Mediterranean Sea. J Plankton Res 18:1837-1849

Guillard RRL, Kilham P (1977) The ecology of marine planktonic diatoms. In: Werner $\mathrm{D}$ (ed) The biology of diatoms Botanical Monographs no. 13, Blackwell Scientific Publications, Oxford, p 372-469

Kayser $H$ (1979) Growth interactions between marine dinoflagellates in multispecies culture experiments. Mar Biol 52:357-369

Kokkinakis SA, Wheeler PA (1988) Uptake of ammonium and urea in the northeast Pacific: comparison between netplankton and nanoplankton. Mar Ecol Prog Ser 43:113-124

Kondo K, Seike Y, Date Y (1990) Red tides in the brackish Lake Nakanoumi. (III) The stimulative effects of organic substances in the interstitial water of bottom sediments and in the excreta from Skeletonema costatum on the growth of Prorocentrum minimum. Bull Plankton Soc Jpn $37: 35-47$

Kristiansen S (1983) Urea as a nitrogen source for the phytoplankton in the Oslofjord. Mar Biol 74:17-24

Levasseur M. Therriault JC, Legendre L (1984) Hierarchical control of phytoplankton succession by physical factors. Mar Ecol Prog Ser 19:211-222

Levasseur M, Thompson PA, Harrison PJ (1993) Physiological acclimation of marine phytoplankton to different nitrogen sources. J Phycol 29:587-595

Lorenzen K, Struve J, Cowan VJ (1997) Impact of farming intensity and water management on nitrogen dynamics in intensive pond culture: a mathematical model applied to Thai commercial shrimp ponds. Aquac Res 28:493-507

Malone TC (1980) Algal size and phytoplankton ecology. In: Morris I (ed) The physiological ecology of phytoplankton Blackwell, Oxford, p 433-463

Mitamura O, Saijo Y (1975) Decomposition of urea associated with photosynthesis of phytoplankton in coastal waters. Mar Biol 30:67-72

Moriarty DJW (1986) Bacterial productivity in ponds used for culture of penaeid shrimps. Microb Ecol 12:259-269

Paerl HW, Tucker CS (1995) Ecology of blue-green algae in aquaculture ponds. J World Aquacult Soc 26:109-131

Phillips MJ, Kwei-Lin C, Beveridge MCM (1993) Shrimp culture and the environment-lessons from the world's most rapidly expanding warmwater aquaculture sector. In: Pullin RSV, Rosenthal H, Maclean JL (eds) Environment and aquaculture in developing countries. ICLARM Conference Proceedings 31:171-197

Pollingher U, Berman T (1982) Relative contribution of net and nano-plankton to primary production in Lake Kinneret. Arch Hydrobiol 96:33-46

Probyn TA (1985) Nitrogen uptake by size-fractionated phytoplankton populations in the southern Benguela upwelling system. Mar Ecol Prog Ser 22:249-258

Rahmatullah M. Boyde TRC (1980) Improvements in the determination of urea using diacetyl monoxime; methods with and without deproteinisation. Clin Chim Acta 107: $3-9$

Raven JA (1984) A cost-benefit analysis of photon absorption by photosynthetic unicells. New Phycol 98:593-625

Robert JM, Vincendeau ML, Maestrini SY, Marion A. (1986) Prises simultanées de l'azote minéral et de l'urée par les algues unicellulaires des claires ostréicoles: effet de la source d'azote sur la nature du peuplement. C R Acad Sci 303:167-170

Sciandra A (1991) Coupling and uncoupling between nitrate uptake and growth rate in Prorocentrum minimum (Dinophyceae) under different frequencies of pulsed nitrate supply. Mar Ecol Prog Ser 72:261-269

Shrestha MK, Kwei Lin C (1996) Phosphorus fertilization strategy in fish ponds based on sediment phosphorus saturation level. Aquaculture 142:207-219

Smayda TJ (1980) Phytoplankton species succession. In Morris I (ed) The physiological ecology of phytoplankton. Blackwell, Oxford, p 493-570

Sommer U (1989) The role of competition for resources in phytoplankton succession. In: Sommer U (ed) Plankton ecology. Springer-Verlag, Berlin, p 57-106

Sommer U (1996) Nutrient competition experiments with periphyton from the Baltic Sea. Mar Ecol Prog Ser 140:161-167

Syrett PJ (1981) Nitrogen metabolism of microalgae. Can Bull Fish Aquat Sci 210:182-210

Thompson PA, Levasseur ME, Harrison PJ (1989) Light 
limited growth on ammonium vs. nitrate: what is the advantage for marine phytoplankton? Lumnol Oceanogr 34: $1014-1024$

Tseng KF, Huang JS, Liao IC (1991) Species control of microalgae in an aquaculture pond. Water Res 25:1431-1437

Tsuzuki M1, Miyachi S (1989) The function of carbonic anhydrase in aquatic photosynthesis. Aquat Bot 34:85-104

Editorial responsibility: Patricia Glibert, Cambridge, Maryland, USA
Tucker CS (1994) Rationale for management of phytoplankton communities in fish ponds. World Aquaculture Society Book of Abstracts, World Aquaculture '94, 14-18 January 1994, New Orleans, Louisiana, USA World Aquaculture Society, Baton Rouge, p 63

Uchida T (1977) Excretion of a diatom-inhibitory substance by Prorocentrum micans Ehrenberg. Jap J Ecol 27:1-4

Submitted: June 10, 1997; Accepted: March 3, 1998

Proofs received from author(s): June 30, 1998 